\title{
Dreaming in quarantine: linguistic analysis of referential process of dreams during COVID-19 pandemic lockdown
}

\author{
Rachele Mariani, ${ }^{1}$ Silvia Monaco, ${ }^{1}$ Christopher Christian, ${ }^{2}$ Michela Di Trani ${ }^{1}$ \\ ${ }^{1}$ Department of Dynamic and Clinical Psychology, and Health Studies, Sapienza University of Rome, Rome, Italy; ${ }^{2}$ City College, \\ City University of New York, New York, NY, USA
}

\begin{abstract}
The spread of coronavirus disease 2019 (COVID-19) became a collective trauma adversely affecting physical and psychological health. The impact of this trauma made itself manifest in a myriad of ways, including through dreams. This study aimed to explore the Referential Process (RP, Bucci, 2021) of dreams reported during quarantine. Dream samples were collected through a social blog. Linguistic analysis and clinical evaluation were conducted to explore the group's collective elaboration of a shared traumatic experience. Sixty-eight people (22 males; mean age 26.16 ds. 7.68) contributed to a social-blog, writing their dreams. 91 dreams were collected and transcribed using transcription rules for the Discourse Attributes Analysis Program (DAAP). Linguistic measures of RP were applied and a statistical cluster analysis was performed. In addition, each dream was evaluated by trained judges on three specific qualities of the RP (Arousal, Symbolizing, and Reflection/Reorganizing). Clinical judges in a double-blinded method reached reliable scoring (Arousal $\alpha .874$ ICC 0.701; Symbolizing $\alpha .783$ ICC 0.671; Reflection/reorganization $\alpha .884$ ICC 0.758). Cluster Analysis yielded three dream clusters. 26 dreams fell under a cluster defined as a symbolizing process (Cluster A); 16 into a cluster defined as arousal of emotional activation (Cluster B); and 49 dreams fell into a cluster defined as Reflection/Reorganizing elaboration (Cluster C). Each cluster showed specific linguistic features. The dreams collected through a blog showed a Referential Process that is similar to that found in psychotherapy process. Results suggests that writing dreams can play different functions in processing and integrating social traumatic experience.

Correspondence: Rachele Mariani, Department of Dynamic and Clinical Psychology, and Health Studies, Sapienza University of Rome, via degli Apuli 1, Rome, Italy.

E-mail: rachele.mariani@uniroma1.it
\end{abstract}

Conflict of interests: the authors declare no potential conflict of interests.

Ethics: all procedures in studies involving human participants were performed in accordance with the ethics standards of institutional and national research committees and with the 1964 Declaration of Helsinki and its later amendments or comparable ethics standards. Ethical approval for the study was provided by the Department the University of the Corresponding author. This is an original, not previously published, manuscript.

Informed consent: informed consent was obtained from all individual participants in the study.

Data accessibility statement: data supporting the results shown in the paper are available from the corresponding author on request.

Citation: Mariani, R., Monaco, S., Christian, C., \& Di Trani, M. (2021). Dreaming in quarantine: linguistic analysis of referential process of dreams during COVID-19 pandemic lockdown. Research in Psychotherapy: Psychopathology, Process and Outcome, 24(2), 176-187. doi: 10.4081/ripppo.2021.537

Received for publication: 12 March 2021.

Revision received: 18 April 2021.

Accepted for publication: 24 April 2021.

This work is licensed under a Creative Commons Attribution NonCommercial 4.0 License (CC BY-NC 4.0).

${ }^{\circ}$ Copyright: the Author(s), 2021

Licensee PAGEPress, Italy

Research in Psychotherapy:

Psychopathology, Process and Outcome 2021; 24:176-187

doi:10.4081/ripppo.2021.537
Key words: Dreams; COVID-19; referential process; collective trauma; linguistic measures.

\section{Introduction}

\section{The role of psychoanalysis during the COVID-19 emergency}

The spread of coronavirus disease 2019 (COVID-19) brought significant changes to daily functions across different spheres of society. In March 2020, the World Health Organization declared a public health emergency of international concern, when upon the Italian government decided to adopt drastic restrictive measures for its citizens (Decree of the President of the Council of Ministers, March 9, 2020) summarized by the term 'lockdown'. The Italian population was required to stay home (except for work, emergencies, or health reasons) for nearly two months.

At first, the psychoanalytical community deliberated the use of new technologies, such as videoconferencing software, that were aimed at ensuring a continuum of clinical work with patients, and these deliberations yielded interesting exchanges (see Miermont-Schilton \& Richard, 2020). It became necessary for the psychoanalytic community to offer its perspective on the impact that the pandemic was likely to have on public health and mental 
functioning (Osserman \& Le, 2020; Birksted-Breen, 2020), just as Freud offered, when he wrote 'Civilization and Its Discontents' (1962) in the late period of his life.

For the first time in a generation, a real and concrete 'collective trauma' (Masiero, Mazzocco, Harnois, Cropley, \& Pravettoni, 2020) struck the world community. In this case, it is impossible to talk about an individual mind without taking into account a collective one, existing in a mutual relationship of interdependence.

The lockdown brought a total disruption of daily routines - a drastic restriction of individual freedom, which threatened the integrity of the Ego (Souza, Pettengill \& Pettengill, 2020). The result of this total interruption of individual and community lives was the activation of different attempts at re-gaining the original state that was upended (Townsend, Eliezer \& Major, 2013). Fear is the common response to a violation of an expected state, or a routine (LeDoux, 1996). We see different manifestations of fear during the pandemic, such as fear of death, fear of infecting or becoming infected. In addition, we observed other phenomena, including the use of war language in talking about the pandemic, the spread of conspiracy theories, and a growing confusion between individual and systemic standpoints (Venuleo, Gelo \& Salvatore, 2020). The recent development of 'the Fear of COVID-19 Scale' (Soraci et al., 2020) was with the purpose of tracking this phenomenon.

Emotions related to the lockdown state have become the subject of research, including loneliness (Killgore et al., 2020), concerns about one's neighbourhood (Lambert et al., 2020), and feelings of anger, and disgust (Kleinberg, Vegt \& Mozes, 2020). Researchers focused on responses elicited by these emotions, determining the most effective defences employed by large groups of people (Gori, Topino \& Di Fabio, 2020). From a psychoanalytic perspective, Bromberg (2013) has highlighted how fear can trigger dissociative reactions in response to trauma. The strong experience of fear mobilizes defensive manoeuvres that increase arousal and ultimately culminate in emotional dysregulation. Clinical and neurobiological evidence (Whelton, 2004; Lane, Ryan, Nadel, \& Greenberg, 2015) suggests that psychological interventions help in decreasing a patient's vulnerability to affective hyperarousal regardless of how minimal the scope of the vulnerability may be. Clinical interventions are aimed at promoting a reduction of dissociated experiences trough a connection between emotional arousal and an experience (or an object). To this end, a blog called Dream Drawer was developed to help people share their experiences and dreams during the COVID-19 pandemic.

This collective elaborating dream project could be seen as part of a larger global interest in dreams and nightmares during the pandemic, such as that of Guardians of Sleep, a project initiated by The Museum of Dreams in partnership with the Museum of London (UK) in which oral testimony was solicited from Londoners about their dream-life during the COVID-19 pandemic (Museum of London, 2020).

\section{Multiple Code Theory in the dreams}

Multiple Code Theory (MCT, Bucci, 2021) represents a conjuncture point between psychoanalysis and cognitive science developed to explain the complexity of emotional processing. According to MCT, information is processed and represented by different systems that can operate in parallel. Bucci has postulated three basic systems in human beings: the subsymbolic system, organizing experience and perceptions in a global and analogical way; the symbolic non-verbal system, comprised of representations, images, and metaphors; and the symbolic verbal system, where finally experience can be coded and shared through the use of words. In processing emotions, the most important step happens between the subsymbolic and the symbolic nonverbal system (Mariani \& De Coro, 2013), when symbols are created. These symbols are the objects that populate our mind. The verbal system facilitates sharing of these symbols by connecting them to words. In this process, inevitably, there is a loss of the original complexity of the first passage described, moving away from the analogical logic of the subsymbolic system.

The three systems are linked by a process called the Referential Process (RP) by which subsymbolic experiences is connected to images and to words. The activation of this process is mutable, depending on different variables such as the context, particular events, or emotional states (Bucci, 2021). Fluctuation in this activation leads to different levels of integration or disconnection between systems. The integration of RP can be assessed by specific measures applied to written or spoken narratives. The first empirical measure developed for this purpose was Referential Activity (RA), a coding system designed to have trained judges manually score transcribed narratives along four dimensions of speech (clarity, specificity, imagery, and concreteness) that were theorized to capture the referential process (Bucci, Kabasakalian, \& the RA Research Group, 2004). Over the last 20 years, a number of computerized programs for scoring referential activity have been developed. The most recent version of these computerized programs is the Weighted Referential Activity Dictionary (WRAD; Maskit, 2021). The WRAD is a sophisticated linguistic measure of emotional immersion or disengagement that has been translated and applied in several languages including Italian (Mariani, Maskit, Bucci, \& De Coro, 2013; Negri et al., 2018; Maskit, 2021; Zhou et al., 2021). A relevant number of studies have validated the referential process measures using clinical and empirical research in psychotherapy process (Negri et al., 2020; Hoffmann, Algus, Braun, Bucci, \& Maskit, 2013), in research of body-mind processes (Di Trani, Mariani, Renzi, Greenman, \& Solano, 2018; Ben-Meir, Bucci \& Bers, 2009), psychopathology and emotional integration (Jepson \& Bucci, 1999; Christian, Hoffman, Bucci, Crimins, \& Worth, 2010). 
High integration of the referential process is related to positive therapeutic change (Bucci, 2021). A central tenet of the transformative process of psychotherapy is related to the effects it has on changing core emotion schemas. Therapeutic change hinges on a new integration of the referential process. In order for this new referential process to evolve in the course of a psychotherapeutic treatment, emotion schemas have to be activated. Emotion schemas are particular types of implicit memory that are built as clusters of memories of events of one's life, which include subsymbolic (sensory, visceral, and motoric processes) activated in relation to different people in different contexts (Bucci, 2021). The therapeutic setting, writing autobiographical memories, or telling or writing dreams, are different activities that can facilitate emotion schema activation. The emotion schemas progress through three phases in order to have any chance of transformation. The three phases are summarized below (Bucci, 2021):

- Arousal phase. In this phase material that is outside or on the periphery of awareness is activated. This can include somatic stirrings, perception of sensory material, activation of an emotion schema, or arousal of a plan for motor action. The emotional activation is strong but not well defined or verbalized. As the activated material is gradually processed, it is classified into a prototypic image or plan for action.

- Symbolizing/Narrative. In this phase, images, or sequence of images associated with the affective core come to mind, perhaps in fleeting or disconnected form, perhaps in waking fantasies, memories, or perhaps as they appear in a dream. The images constitute instantiations of an emotion schema that has been activated. Verbal communication of emotional experience depends on such detailed descriptions; the person tells what happened as if he/she is there, experiencing the event; which can induce in the listener the feeling that they there as well.

- Reflection/Reorganization. Once the material is verbalized, and the affect is present but sufficiently contained, there is an opportunity for a reorganizing phase in which the source and meaning of the events that make up the schema may be further explored, allowing for new connections to be discovered, and new schemas to be constructed.

RP facilitates the understanding of the work of processing emotions, especially the integration of emotional experience in dreams. Dreams are par excellence the trait d'union of the subsymbolic and symbolic system. Moreover, precisely because of their properties, some dreams are easier to describe verbally, while other dreams are more emotionally activating but more complex to verbalize (Severino, Bucci \& Creelman, 1989).

Variations in the referential process are appreciable also in reports of dreams, and a measure of the referential process, Referential Activity, can vary by dream. Higher RA language is characterized by being well integrated, more vivid, specific, full of imagery, and evocative. This is clear in the dream-studies focused on alexithymia, a dimension characterized by a problematic connection among the three systems, with naturally low levels of RA (Bucci, 2008; Di Trani et al., 2018). Research in the referential process and dreams show that poor RP is related to a low dream recall capacity (De Gennaro et al., 2003) and dreams are characterized as boring and lacking vividness (Lumley \& Bazydlo, 2000). Narratives characterized by a boring language, where there is a total absence of emotional words or enlightening symbolizations, are associated to a low RA also in the clinical experience (Taylor, 1987). In other words, through language use we can trace the connection or integration between symbolic and subsymbolic systems. It can also be hypothesized that the connection with these primordial systems can be facilitated during the act of dreaming, as images and symbols are predominant in dream narratives.

\section{Pandemic dreams}

Usually, dreams reflect events of everyday life, drawing on material from daytime events. Freud (1900) used the term day residue to refer to the day's events that work themselves into a dream. In the context of dream research, the continuity hypothesis of dreaming postulates that dream contents are a reflection of the day's activities (Schredl, 2012). This phenomenon is appreciable in studies on the correlation between trauma and dream content, where repercussions of the traumatic event are made manifest in dreams (Miller, Brownlow, Woodward, \& Gehrman, 2017).

The lockdown experience, defined previously as a collective trauma, should have influenced not only the waking life of the community, but also in their dream life.

A communitarian conception of dreams can be traced to the work of Gordon Lawrence (1998) and his colleagues at the Tavistock Institute and Tavistock Clinic in the 1980s. This group of researchers and clinicians developed a practice they termed 'social dreaming', in order to identify social trends and social dynamics in the dreams of a group. According to this approach, the dreams of a community can represent a key to the unconscious of a society (Neri, 2004). This social unconscious underlines the social nature of the human being also in its deepest parts, treating unknown emotions and images shared by different people (Hopper \& Weinberg, 2011).

Parallel to this clinical practice, there is a field of sociological research that investigates the world of dreams, focusing on sociological aspects (Lahire, 2020). There have been studies exploring the correlation between catastrophic events and their impact on community dreams (Hartmann $\&$ Basile, 2003; Schredl \& Piel, 2006), but these situations are differed in important respects from the reality of COVID-19. The pandemic affected the entire world, and has persisted for a long period time (over one year, to date). The uniqueness of the pandemic, has prompted researchers 
to examine the impact of different facets of on the general population. Recently, a number of studies have turned their attention to dreams as they relate to the effects of restrictive measures that have been implemented (Iorio, Sommantico \& Parrello, 2020; Barrett, 2020; Mota et al., 2020; Pesonen et al., 2020; MacKay \& DeCicco, 2020). This type of research has received little attention, reflecting a lacunae in the scientific community, and a pressing need to develop new approaches to examine the unique impact of COVID19 on dream life.

We hypothesized that dream narratives reflect an emotional and cognitive working through of the lockdown experience. This working through process can be detected through different linguistic measures, according to the MCT (Bucci, 2021).

\section{Aims of the study}

The purpose of this study is to investigate the emotional process present in dreams that occurred during the COVID-19 pandemic as assessed by referential process measures and using as a framework of study the Multiple Code Theory. Specifically, we assume that dreams can differ in how they represent different stages of the arousal process, such that some dreams are marked by arousal; while others may be marked by symbolization or by reflection/reorganizing.

To test our hypothesis: i) clinical judges evaluated dreams on three scales related to different stages of the referential process (Arousal, Symbolization, and Reflection/Reorganizing scores); ii) computerized RP linguistic measures were applied to the collected dreams, and then used to conduct a cluster analysis to determine whether dreams can be distinguished along the dimensions of the language measures; iii) findings from the cluster analysis were then compared to clinical ratings by judges.

Finally, we explored the relationships between sociodemographic variables of the sample and findings from the linguistic measures applied to their dreams.

\section{Materials and Methods}

\section{Procedures}

Data was collected from a blog called the 'Dream Drawer'. This blog was designed to collect narratives of dreams at a time when the population was attempting to process and integrate the emotional trauma generated by the impact of the COVID-19 pandemic. The blog was free and accessible to anyone interested in writing about their dreams and experiences related to the lockdown. Each participant provided informed consent for research participation, completed a sociodemographic questionnaire and, were given access to the blog to submit their dreams. Participants were identified by nickname. The blog remained open from the middle of April to the middle of May 2020, when restrictive measures were lifted. After the closing of the 'Dream-Drawer', all the transcripts were transcribed using transcription rules (Maskit, 2014) and collected in a database protected by a password. This study was carried out in accordance with the code of ethics of the World Medical Association (Declaration of Helsinki) for experiments involving humans. Ethical approval was granted by the ethics committee of the University Department of Dynamic and Clinical Psychology, and Health Studies, Sapienza University.

\section{Participants}

The sample was of convenience and it was recruited from the general Italian population in a snow-ball method. A total of 68 individuals self-registered in the blog, and consisted of 22 males and 46 females. The mean age was $26.16(\mathrm{SD}=7.7) .21$ had graduated from high school and $47 \mathrm{had}$ a post-graduate degree. 10 participants lived alone, 42 with family and 16 with cohabitants; 27 described themselves as single, and 41 were engaged. Thirty-five participants were in psychotherapy treatment. Twenty participants were in contact with someone who had either been infected or had died from COVID-19. A total of 91 dreams were collected from these participants.

\section{Measures}

\section{Sociodemographic questionnaire}

The self-administered questionnaire was an integrated part of the blog and it collected data on multiple variables concerning; age, gender; level of education; living arrangements, relationship status; and whether the participant knew someone infected or had died by COVID-19.

\section{Computerized Referential Process linguistic measures}

The Discourse Attribute Analysis Program (DAAP; Maskit, 2021) is a computer software program that compares any type of text with lists of words (referred to as dictionaries) in order to determine the proportion in which those words are present in the text and also the intensity with which a speaker is communicating about a particular construct. The latter is done through the use of 'weighted' dictionaries, in which specific words are weighed according to how they reflect different constructs. DAAP reads texts, compares them word by word to one or more dictionaries, and calculates a weighted average of the dictionary scores for each speaker and each turn of speech, for each text, and for each session. In our study, we used the following dictionaries and derived measures built and validated for the Italian language (Table 1):

The Italian Weighted Referential Activity Dictionary (IWRAD) is a computerized measure of RA (Mariani et al., 2013) in the Italian language. It contains a list of 9596 frequently used Italian words, each assigned a weight between 0 and 1 , with 0.5 as the neutral value. A high score represents a high level of RA, which corresponds to a high level of concreteness, specificity, clarity, and imagery in 
the speech sample. Part of the value of the IWRAD derives from its power to assess a particular linguistic style (rather than only focusing on content) and to represent the unintended aspects of emotional involvement. For a deeper discussion on the method of building a weighted dictionary like IWRAD, see Maskit (2021).

The Italian Weighted Reflection and Reorganization List (IWRRL). IWRRL is a computerized measure of the reflection and reorganization process in the Italian language. It contains a list of 1633 frequently used Italian words, each assigned a weight between 0 and 1 , with 0.5 as the neutral value (Negri et al., 2018). A high score on this measure represents high competence in reorganization and reflection in speech, referring to the degree to which the speaker is trying to recognize and understand the emotional significance of an event or set of events in their own or someone else's life, or in a dream or fantasy. It is not about abstract reflection, but rather a person's reasoning related to an experience that has been vividly experienced. Through IWRRL, it is possible to detect and model the reorganizing phase of the referential process.

The Italian Sensory Somatic Dictionary (ISenS) is a list of 1926 Italian words related to the body and bodily activities, and to sensory processes and/or descriptions of symptoms (Di Trani et al., 2018). The number of ISensD words in a speech sample is a measure of the arousal of bodily, sub-symbolic aspects of emotion schemas.

The Italian Sum Affect Dictionary (ISAff) contains 1786 Italian words concerning how people feel and communicate feelings directly. It includes emotion labels, functions associated with affective arousal, and words indicating an emotional response, either positive or negative.

\section{Grid for clinical evaluation by judges}

A group of four judges, were trained to assess Referential Activity using manual coding and phases of the Referential Process in double blinded method (Kingsley, 2010). The judges scored each single dream following three definitions of Arousal, Symbolizing and Refection/Reorganizing process. For each definition the judge must indicate a value between 0 and 10. The reliability index of the judges was evaluated through the alpha of Cronbach and interclass correlation (ICC).

\section{Data analysis}

The statistical analyses were conducted using the Statistical Package for Social Science (SPSS) version 26 for Windows (IBM, Armonk, NY, USA). Data were reported as frequencies and percentages for discrete variables, and as means and standard deviations for continuous variables.

After the linguistic measures were applied to the dream texts, we conducted a cluster analysis, which enables the categorization of dreams on the basis of their linguistic features of set of variables of RP. This approach allows researchers to identify groups of quality of dream emotional process.

One-way analyses of variance (ANOVAs) were conducted on the groups identified by the cluster analysis, and were compared to judges 'clinical evaluation of each dream (Arousal, Symbolizing and Reflection-Reorganizing scores).

Finally, the relationships between linguistic measures and demographic variables were analysed using Pearson's correlation analysis for continuous variables and one-way ANOVAs for categorial variables.

\section{Results}

\section{Cluster analysis of dreams by linguistic measures}

As a first step, a hierarchical Cluster Analysis using Ward's method was run, and all linguistic measures were inserted for the cluster analysis. We then adopted the squared Euclidean distance to determine profiles of dreams according to their $z$-scores on each linguistic measure (Hair et al., 2009). The hierarchical Cluster

Table 1. Examples of words belonging to Italian linguistic measures of the Referential Process.

IWRAD high weight: odore (smell $=0.981$ ); maledetto (damned $=0.890)$; urla (scream=0.835); stupore (astonishment $=0.786$ ); baciare (to kiss $=0.747)$;IWRAD medium weight: il (the $=0.058)$; capisci (you understand $=0.0314)$; io $(\mathrm{I}=0.018)$; lei $($ she $=0.008)$, ciò $($ that $=-0.011)$; tu $($ you $=-$ 0.042 ) IWRAD low weight: superficiali (superficial $=-0.870$ ); parlavamo (we talked $=-0.870$ ); ansiosa (anxious $=-0.867$ ); capiscono (they understand $=$ $-0.654)$; carini (nice $=-0.519$ )

IWRRL High weight: anticipazione (anticipation $=0.898)$; impedisce (prevent $=0.796)$ spensierata (carefree $=0.786)$ bisogni $($ needs $=0.738)$ simbolicamente (symbolically=0.734).IWRRL Medium weight: no (no $=0.015)$; chiaramente (clearly $=0.006)$; discorso $($ speech $=0.008)$; logicamente $($ of course $=-0.01)$; problemi (problems $=-0.013$ ). IWRRL low weight: separazione (separation $=-0.571)$; chiamare (To call $=-0.500)$; dipende $($ depend $=-0.455)$; scelta (choise $=-0.370)$; giocavo $($ I played $=-0.370)$

ISenSD: Ammalato (sick), digerire (digest), disorientamento (disorientation), dolore (pain), impotente (impotent), innervosito (unnerved), pesare (weigh), ridere (laugh), sintomi (symptoms), vomitare (throw up)

ISAffD: Sum of all Positive, Negative, Neutral Affect Dictionaries as global affect list; Negative: Abbandonato (abandoned), depresso (depressed), impaurito (frightened), invidioso (envious), malinconia (gloom), odio (hate), sofferenza(suffering). Positive: Abbracci (hugs), affidabile (reliable), baciare (to kiss), felice (happy), innamorato (in love), speranza (hope). Neutral: Attesa (expectation), bisogno (need), coinvolto (involved), eccitato (excited) intensità (intensity), motivazione (motivation), reagire (react), sensazione (feeling)

IWRAD, Italian Referential Activity Dictionary; IWRRL, Italian Weighted Reflection-Reorganizing List; ISenSD, Italian Sensory-Somatic Dictionary; ISAffD, Italian Dictionary of respectively Sum, Positive, Negative, Neutral (Z) Affects. 
Analysis suggested a three-cluster solution as shown by an examination of the dendrogram (Figure 1). The Bayesian Index Criterion confirmed the three-cluster solution, as the lowest value was observed for this solution. In a second step, to validate the three-cluster solution a kmean Cluster Analysis on the numbers of clusters emerging in the hierarchical Cluster Analysis was run. $\mathrm{A} \mathrm{N}=26$ dreams belong to Cluster A, which has Referential Activity (IWRAD) and Senso-somatic (ISenSD) over the mean. $\mathrm{N}=16$ dreams belong to Cluster $\mathrm{B}$, which has all measures over the mean, the higher is related to Sum of affects (IAffSD). Then $\mathrm{N}=49$ dreams belong to Cluster $\mathrm{C}$, which has all the measure below the mean except for ReflectionReorganization (IWRRL) (see Figure 2).

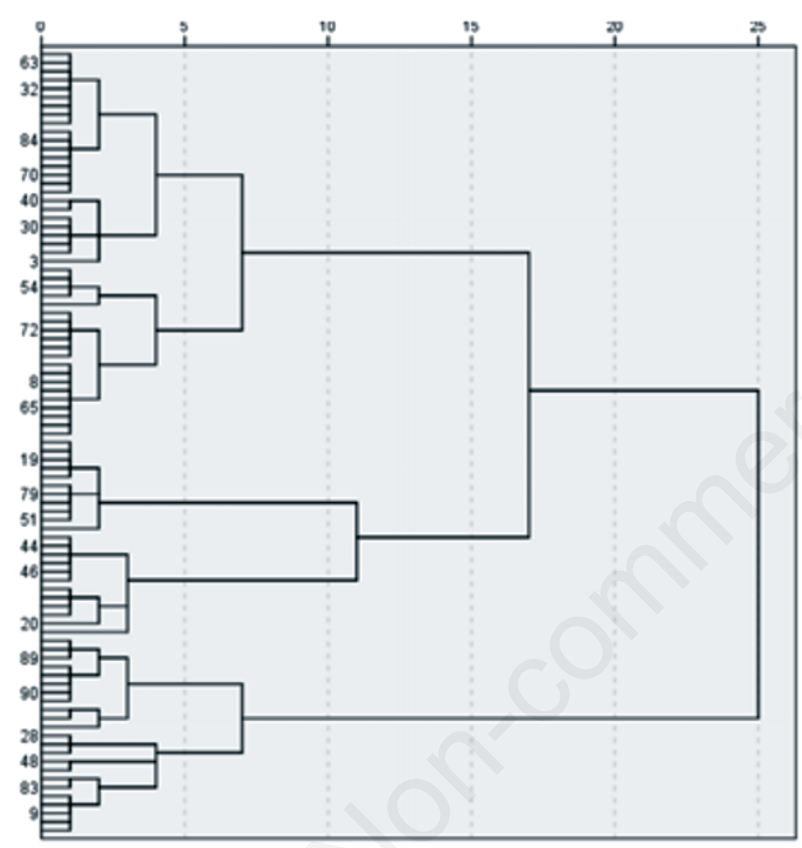

Figure 1. Dendrogram of hierarchical Cluster Analysis using the Ward method.

\section{K-mean Cluster Analysis}

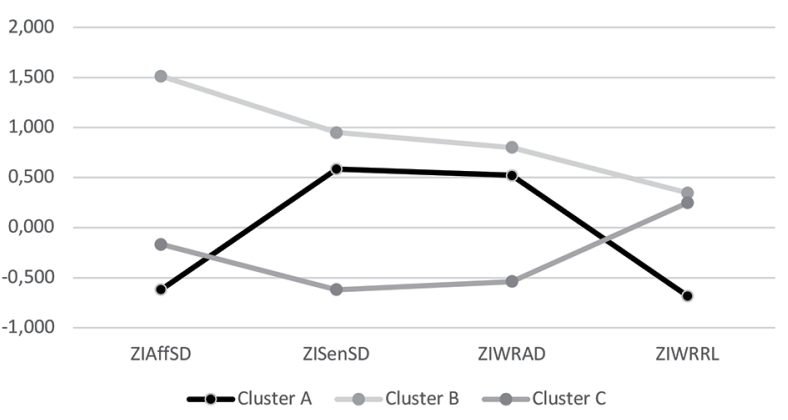

Figure 2. K-Mean Cluster Analysis.

\section{Qualitative exemplification of dreams in each cluster}

Dreams clustered by linguistic measures appear to have different narrative qualities which also imply a different emotional function. Below we will report the dreams that the cluster analysis resulted closest to the centre of the assigned cluster.

\section{Cluster 1: Symbolizing Dream}

\section{Mare mosso a XXX}

Mi trovo nella mia casa a XXX, mia mamma è venuta a trovarmi e nota della muffa sul tetto dicendomi che deve subito essere pulita per toglierla. Nel frattempo tra noi si crea tensione, non ricordo per cosa, e noto che la casa è molto stretta e senza i muri interni, ci sono solo quelli esterni con 3 finestre che danno su un piccolo pianerottolo esterno oltre il quale c'è il mare. Mia mamma dice di non sapere che a XXX ci fosse il mare, rimango perplesso pure io ed ipotizzo sia il Tevere. Iniziamo a stendere i panni quando noto che l'acqua si fa sempre più nera e inizia ad aumentare, dico a mia mamma di rientrare perché il livello dell'acqua sta crescendo, ma proprio in quel momento le onde iniziano a farsi sempre più alte e iniziano a sbattere contro di noi e contro il muro, io riesco a scavalcare la finestra per rientrare ma mia madre ha qualche difficoltà. Impaurito nel mezzo del sogno mi sveglio.

[Rough sea at XXX: I am in my house in XXX, my mom has come to see me and she notices mold on the roof, she told me that it needs to be cleaned immediately to get it out. In the meantime, tension is created between us, I don't remember what, and I notice that the house is very narrow and without the internal walls, there are only the external ones with three windows that overlook a small external landing beyond which there is the sea. My mother says she does not know that there was a sea in XXX, I am also perplexed and I assume it is the river. We start drying the clothes when I notice that the water is getting darker and starting to rise, I tell my mom to come back because the water level is rising, but at that moment the waves start to get higher and higher and they start banging against us and against the wall, I manage to climb over the window to get back in but my mother has some difficulties. Afraid in the middle of the dream I wake up.]

\section{Cluster 2: Arousal Dream}

\section{Stalker}

Il sogno di ieri notte è stato particolarmente faticoso, ne sento ancora il peso. Mi trovo in una strada affollata mi guardo intorno, sono impaurita e confusa, ho il fiatone e sto sudando, sento degli occhi addosso ma non riesco a capire di chi sia lo sguardo, non mi piace. Inizio a correre, voglio trovare riparo. Corro, corro, corro, non do retta alla direzione, sto solo cercando di togliermi di dosso quegli occhi. [...] Ho il cuore che batte fortissimo, sono stanca, fatico a respirare. Raggiungo l'ultimo piano e il mio appartamento, entro chiudendo la porta. Mi sento al 
sicuro, sollevata. Davanti a me nel salotto vedo $i$ miei coinquilini. Mi guardano preoccupati. Io mi dirigo verso il bagno, ho bisogno di una doccia, sento la necessità di lavarmi via di dosso la sensazione di quello sguardo. Guardo fuori e gli occhi che mi hanno seguita per tutto questo tempo sono di fronte a me e mi fissano penetranti. Sono intrappolata dalla loro forza e una paura totalizzante mi investe Il volto che li ospita si apre in un sorriso malevolo e una sola parola risuona nella mia testa: presa! Il sogno si è interrotto cosi ed io mi sono svegliata stanchissima, ancora adesso mentre scrivo sento una stanchezza incredibile.

[Last night's dream was particularly tiring. I still feel the weight of it. I find myself in a crowded street. I look around, I am afraid and confused, I am out of breath and I am sweating, I feel eyes on me but I cannot understand whose look it is, I don't like it. I start running, I want to find shelter. I run, I run, I run, I don't listen to direction, I'm just trying to get those eyes off me. [...] My heart is beating very fast, I'm tired, I struggle to breathe. I reach the top floor in my apartment, I enter by closing the door. I feel safe, relieved. In front of me in the living room I see my roommates. They look at me worried. I head to the bathroom, I need a shower, I feel the need to wash off the feeling of that look. I look out and the eyes that have been following me all this time are in front of me and stare at me piercingly. I am trapped by their strength and an allencompassing fear hits me. The face that hosts them opens in a malevolent smile and a single word resounds in my head: take! The dream stopped like this and I woke up very tired, even now as I write I feel an incredible tiredness.]

\section{Cluster 3: Reflecting and Reorganizing Dream}

\section{Test d'ingresso}

Sono dentro un'aula decadente, un tizio urla che mancano 5 minuti alla consegna, allora realizzo che sto facendo il test d'ingresso per la magistrale. Scatta il panico, non ho messo ancora nemmeno una crocetta e mentre mi maledico perché fino a quel momento non capisco dove avessi la testa, cerco di mettere qualche crocetta. Ma mi rendo conto che il test è già compilato, anzi è pure scarabocchiata ed è il test di un'altra persona! Chiamo il tizio che urlava e gli dico che deve cambiarmi il foglio, che quel compito non è mio, ma lui mi mette in mano 20 euro e mi dice che il mio test è invalidato. Allora mi arrabbio, dico che è ingiusto, inveisco contro questo tizio ma mi rendo conto che in effetti... Io sono al primo anno della magistrale.... perché dovrei fare il test? Non ha senso, l'accesso al secondo anno è senza test! E così mi rilasso, prendo le mie cose e mentre sto per andare via la mia vicina di banco mi bisbiglia 'hey mi dispiace che non hai sviluppato l'immunità' mi guarda come se stessi per andare a morire, la guardo disorientata, penso che si è sbagliata e vado verso la porta. Sopra la porta c'è il cartellone 'Test COVID-19'.

[I am in a decadent classroom, a guy screams that there are 5 minutes to delivery, then I realize that I am taking the entrance test for the master's degree. Panic starts, I have not even made a mark yet and while I curse myself because until that moment I do not understand where my head was, I try to put some marks. But I realize that the test is already filled in, indeed it is even scribbled and it is another person's test! I call the screaming guy and tell him that he has to change my paper, that that task is not mine, but he puts 20 euros in my hand and tells me that my test is invalid. So I get angry, I say it's unfair, I rail against this guy but I realize that in fact / I'm in the first year of the master's / why should I take the test? It makes no sense, access to the second year is without tests! And so I relax, I take my things and as I am about to leave my neighbor whispers to me 'hey I'm sorry that you haven't developed immunity' she looks at me as if I were going to die, I look at her disoriented, I think that she was wrong and I go to the door. Above the door is the 'Test COVID-19'sign.]

\section{Clinical judges' evaluation and computerized linguistic analysis comparison}

Four clinical judges, double-blinded, evaluated 91 dreams scoring three specific definitions: Arousal, Symbolizing and Reflection-Reorganizing process. Reliability was measured among them for each definition: Arousal (Cronbach alpha 0.874 icc .701); Symbolizing (Cronbach alpha 0.783 icc 0.671); Reflection/reorganization (Cronbach alpha 0.884 icc 0.758 ).

One-way Anova have been applied to clusters and judges' scoring (Table 2), showing significant differences between the cluster of dreams on all the clinical scores.

Consistent with our hypothesis, Bonferroni post-hoc analyses on clusters and clinical judges' evaluation showed the following significant differences: i) Arousal scores were higher in Cluster 2 (Arousal dreams), than Cluster 1 (Symbolizing Dream) and Cluster 3 (Reflecting and Reorganizing Dream) $(\mathrm{P}<0.05)$; ii) Symbolizing scores were higher in Cluster 1 (Symbolizing Dream), than Cluster 3 (Reflecting and Reorganizing Dream) $\mathrm{P}<0.05)$; iii) Reflection-Reorganizing scores were higher in Cluster 3 (Reflecting and Reorganizing Dream), than Cluster 1 (Symbolizing Dream) and Cluster 2 (Arousal dreams) $(\mathrm{P}<0.05)$.

\section{Descriptive variables and Referential Process linguistic measures}

As shown in Table 3, linguistic analysis did not show any differences between: gender; living arrangement; level of education, and knowing someone infected or who died by COVID-19. Age showed a positive significant correlation to Negative Affect (NAFFD), which increased by age $(\mathrm{r}=0.243 \mathrm{P}<0.5)$. Negative Affect also was significantly higher in participants who indicated that they were in a relationship versus participants who were single 
Table 2. One-way ANOVAs between the three cluster dreams groups and judges' clinical evaluation of arousal, symbolizing and reflection-reorganization process.

\begin{tabular}{|c|c|c|c|c|c|c|c|c|}
\hline & \multicolumn{2}{|c|}{$\begin{array}{c}\text { Cluster } 1 \\
\text { Symbolizing Dream } \\
\text { No. } 26\end{array}$} & \multicolumn{2}{|c|}{$\begin{array}{c}\text { Cluster } 2 \\
\text { Arousal Dream } \\
\text { No. } 16\end{array}$} & \multicolumn{2}{|c|}{$\begin{array}{c}\text { Cluster } 3 \\
\text { Reflecting and } \\
\text { Reorganizing Dream } \\
\text { No. } 49\end{array}$} & \multirow[b]{2}{*}{$\mathbf{F}$} & \multirow[b]{2}{*}{$\mathbf{P}$} \\
\hline & $\mathbf{M}$ & Sd & $\mathbf{M}$ & Sd & $\mathbf{M}$ & Sd & & \\
\hline Arousal & 3.15 & 1.190 & 7.00 & 1.750 & 3.82 & 1.592 & 40.106 & 0.000 \\
\hline Symbolizing & 6.38 & 1.414 & 5.56 & 1.652 & 4.98 & 2.129 & 5.851 & 0.004 \\
\hline Reflection-Reorganization & 4.85 & 1.523 & 4.50 & 1.785 & 6.14 & 1.443 & 9.002 & 0.000 \\
\hline
\end{tabular}

M, mean; Sd, standard deviation.

Table 3. Descriptive variables and Referential Process linguistic measures.

\begin{tabular}{|c|c|c|c|c|c|c|c|c|}
\hline & No. & $\begin{array}{c}\text { Mean IAffN } \\
\text { (Sd) }\end{array}$ & $\begin{array}{l}\text { Mean IAffP } \\
\text { (Sd) }\end{array}$ & $\begin{array}{l}\text { Mean IAffS } \\
\text { (Sd) }\end{array}$ & $\begin{array}{l}\text { Mean IAffZ } \\
\text { (Sd) }\end{array}$ & $\begin{array}{l}\text { Mean ISenS } \\
\text { (Sd) }\end{array}$ & $\begin{array}{l}\text { Mean IWRAD } \\
\text { (Sd) }\end{array}$ & $\begin{array}{c}\text { Mean IWRRL } \\
\text { (Sd) }\end{array}$ \\
\hline \multicolumn{9}{|l|}{ Gender } \\
\hline Male & 22 & $\begin{array}{c}0.016 \\
(0.0 .010)\end{array}$ & $\begin{array}{c}0.011 \\
(0.070)\end{array}$ & $\begin{array}{c}0.029 \\
(0.140)\end{array}$ & $\begin{array}{c}0.004 \\
(0.005)\end{array}$ & $\begin{array}{c}0.065 \\
(0.030)\end{array}$ & $\begin{array}{c}0.520 \\
(0.006)\end{array}$ & $\begin{array}{c}0.540 \\
(0.004)\end{array}$ \\
\hline Female & 46 & $\begin{array}{c}0.015 \\
(0.010)\end{array}$ & $\begin{array}{c}0.010 \\
(0.060)\end{array}$ & $\begin{array}{c}0.030 \\
(0.170)\end{array}$ & $\begin{array}{c}0.004 \\
(0.007)\end{array}$ & $\begin{array}{c}0.062 \\
(0.030)\end{array}$ & $\begin{array}{c}0.510 \\
(0.005)\end{array}$ & $\begin{array}{c}0.550 \\
(0.007)\end{array}$ \\
\hline \multicolumn{9}{|l|}{ Level of instruction } \\
\hline Graduated & 21 & $\begin{array}{c}0.015 \\
(0.0 .020)\end{array}$ & $\begin{array}{c}0.011 \\
(0.008)\end{array}$ & $\begin{array}{c}0.030 \\
(0.160)\end{array}$ & $\begin{array}{c}0.004 \\
(0.006)\end{array}$ & $\begin{array}{l}0.063 \\
(0.02)\end{array}$ & $\begin{array}{c}0.515 \\
(0.007)\end{array}$ & $\begin{array}{c}0.550 \\
(0.006)\end{array}$ \\
\hline Post-graduate Degree & 47 & $\begin{array}{c}0.016 \\
(0.0 .010)\end{array}$ & $\begin{array}{c}0.008 \\
(0.007)\end{array}$ & $\begin{array}{c}0.027 \\
(00.130)\end{array}$ & $\begin{array}{c}0.004 \\
(0.005) \\
\end{array}$ & $\begin{array}{c}0.063 \\
(0.030) \\
\end{array}$ & $\begin{array}{c}0.516 \\
(0.008) \\
\end{array}$ & $\begin{array}{c}0.560 \\
(0.005) \\
\end{array}$ \\
\hline \multicolumn{9}{|l|}{ To live } \\
\hline Alone & 10 & $\begin{array}{c}0.015 \\
(0.017)\end{array}$ & $\begin{array}{c}0.009 \\
(0.008)\end{array}$ & $\begin{array}{l}0.029 \\
(0.14)\end{array}$ & $\begin{array}{c}0.004 \\
(0.005)\end{array}$ & $\begin{array}{c}0.061 \\
(0.030)\end{array}$ & $\begin{array}{c}0.515 \\
(0.009)\end{array}$ & $\begin{array}{c}0.548 \\
(0.004)\end{array}$ \\
\hline In family & 42 & $\begin{array}{c}0.014 \\
(0.018)\end{array}$ & $\begin{array}{c}0.010 \\
(0.009)\end{array}$ & $\begin{array}{l}0.028 \\
(0.15)\end{array}$ & $\begin{array}{c}0.004 \\
(0.006)\end{array}$ & $\begin{array}{c}0.062 \\
(0.020)\end{array}$ & $\begin{array}{c}0.516 \\
(0.006)\end{array}$ & $\begin{array}{c}0.547 \\
(0.006)\end{array}$ \\
\hline Cohabitant & 16 & $\begin{array}{c}0.015 \\
(0.017)\end{array}$ & $\begin{array}{c}0.008 \\
(0.007)\end{array}$ & $\begin{array}{c}0.028 \\
(0.150)\end{array}$ & $\begin{array}{c}0.004 \\
(0.006)\end{array}$ & $\begin{array}{c}0.063 \\
(\mathrm{ds} 0.030)\end{array}$ & $\begin{array}{c}0.516 \\
(0.008)\end{array}$ & $\begin{array}{c}0.547 \\
(0.005)\end{array}$ \\
\hline Relationship & & & & & & & & \\
\hline Single & 27 & $\begin{array}{l}0.015^{*} \\
(0.014)\end{array}$ & $\begin{array}{c}0.011 \\
(0.007)\end{array}$ & $\begin{array}{c}0.027 \\
(0.013)\end{array}$ & $\begin{array}{c}0.004 \\
(0.006)\end{array}$ & $\begin{array}{c}0.063 \\
(0.026)\end{array}$ & $\begin{array}{c}0.515 \\
(0.006)\end{array}$ & $\begin{array}{c}0.547 \\
(0.004)\end{array}$ \\
\hline Engaged & 41 & $\begin{array}{l}0.018^{*} \\
(0.011)\end{array}$ & $\begin{array}{c}0.010 \\
(0.008)\end{array}$ & $\begin{array}{c}0.028 \\
(0.014)\end{array}$ & $\begin{array}{c}0.004 \\
(0.005)\end{array}$ & $\begin{array}{c}0.064 \\
(0.300)\end{array}$ & $\begin{array}{c}0.516 \\
(0.007)\end{array}$ & $\begin{array}{c}0.546 \\
(0.003)\end{array}$ \\
\hline \multicolumn{9}{|l|}{ Psychotherapy } \\
\hline Yes & 35 & $\begin{array}{c}0.014 \\
(0.008)\end{array}$ & $\begin{array}{c}0.012 \\
(0.008)\end{array}$ & $\begin{array}{c}0.029 \\
(0.016)\end{array}$ & $\begin{array}{c}0.004 \\
(0.006)\end{array}$ & $\begin{array}{l}0.055^{*} \\
(0.025)\end{array}$ & $\begin{array}{l}0.520^{*} \\
(0.009)\end{array}$ & $\begin{array}{c}0.548 \\
(0.005)\end{array}$ \\
\hline Not & 33 & $\begin{array}{c}0.015 \\
(0.011)\end{array}$ & $\begin{array}{c}0.014 \\
(0.009)\end{array}$ & $\begin{array}{c}0.027 \\
(0.010)\end{array}$ & $\begin{array}{c}0.005 \\
(0.005)\end{array}$ & $\begin{array}{l}0.067 * \\
(0.030)\end{array}$ & $\begin{array}{l}0.500^{*} \\
(0.004)\end{array}$ & $\begin{array}{c}0.547 \\
(0.004)\end{array}$ \\
\hline \multicolumn{9}{|c|}{ To know someone infected/died by COVID-19 } \\
\hline Yes & 20 & $\begin{array}{c}0.014 \\
(0.0 .010)\end{array}$ & $\begin{array}{c}0.011 \\
(0.050)\end{array}$ & $\begin{array}{c}0.029 \\
(0.130)\end{array}$ & $\begin{array}{c}0.004 \\
(0.006)\end{array}$ & $\begin{array}{c}0.063 \\
(0.030)\end{array}$ & $\begin{array}{c}0.510 \\
(0.006)\end{array}$ & $\begin{array}{c}0.540 \\
(0.006)\end{array}$ \\
\hline Not & 48 & $\begin{array}{l}0.015 \\
(0.02)\end{array}$ & $\begin{array}{l}0.011 \\
(0.06)\end{array}$ & $\begin{array}{l}0.030 \\
(0.15)\end{array}$ & $\begin{array}{c}0.004 \\
(0.008)\end{array}$ & $\begin{array}{l}0.062 \\
(0.02)\end{array}$ & $\begin{array}{c}0.510 \\
(0.007)\end{array}$ & $\begin{array}{c}0.550 \\
(0.007)\end{array}$ \\
\hline
\end{tabular}

IWRAD, Italian Referential Activity Dictionary; IWRRL, Italian Weighted Reflection-Reorganizing List; ISenS, Italian Sensory-Somatic Dictionary; ISAff, Italian Dictionary of respectively Sum, Positive, Negative, Neutral (Z) Affects; Sd, standard deviation. Significant mean differences $* \mathrm{P}<0.05$. 
$(\mathrm{F}=4.418 \mathrm{P}<0.059)$. Participants in psychotherapy versus not in psychotherapy showed higher Referential Activity (IWRAD: $\mathrm{F}=5.087 \mathrm{P}<0.05$ ) and lower Sensory-Somatic language $(\mathrm{F}=3.849 \mathrm{P}<0.5)$. No correlations emerged between perceived stress levels and the linguistic measures.

Regarding cluster groups, chi-square analysis for categorical variables of social-demographic questionnaire (relationship status; psychotherapy status; and knowing someone infected/died by COVID-19) and clusters was applied: the only significant relationship was for psychotherapy status, where people is psychotherapy wrote more dreams in cluster $3\left(\chi^{2}=6.536 \mathrm{P}=0.038\right)$.

\section{Discussion}

During the first quarantine that took place in March 2020 in Italy, a group of students launched an initiative, inviting people to write their dreams while they were forced to stay at home to contain the spread of the virus. 68 people responded to this initiative, writing down one or more dreams on the blog, and reading the dreams of others. The aim of our work was to analyse the different narrative styles present in these dreams. Many disciplines have explored the function of dreams, and in particular psychoanalysis explored their functions in relation to human psyche. Dreams allow for the working through and processing of emotional arousal, drawing on the day's events (Solms, 2001; Margherita, Gargiulo \& Martino, 2015; Freud, 1900). Thanks to these studies that have highlighted the importance that dreams have in the process of elaborating affects and traumatic experiences, many projects during the pandemic sought to explore the dream function during this period. Some studies have focused on the historical narrative function of dreams and nightmares, while others have focused on content analysis and socio-demographic differences (Barrett, 2020; Museum of London, 2020).

A qualitative analysis of dreams explored in a completely innovative way how a group of people, using the unique resource of social sharing allowed during the lockdown, tried to process the traumatic experience through dreams. According to MCT, the narration and writing of dreams is one of the prevailing ways to link experiences encoded in three different coding systems. The first research question was to determine whether phases of the referential process (arousal, symbolizing, and reflection/reorganizing) that have been found in clinical material could be identified in dreams. The cluster analysis confirmed three distinct qualities of narratives, and the types of narratives were confirmed by clinical evaluation of judges. The clinical assessment discriminated best between Arousal dreams and Reflection/Reorganizing dreams, but was less discriminating of dreams representing a symbolizing process.

The distribution of dreams inside the three clusters was not equal: Cluster $3(\mathrm{~N}=49)$ was the largest, and Cluster $2(\mathrm{~N}=16)$ was the smallest. This could be explained by two conditions. First, dreams where there is a major level of Arousal could be more difficult to remember and to share in words, implying difficulties in translating the raw sensory experience of dreams into words. Second, it is likely that people prefer to write about more organized and coherent dreams, than arousal dreams with no linear logic. Moreover, the writing process is part of reflection activity and it forces people to present the material in a more organized way. However, our results show that affective processes in dreams are not the same and are distinguishable, such that some dreams have more sub-symbolic material, while others are more verbal (symbolic) and well-organized narrations. The three dream examples clearly showed different qualities of narrative styles connected to arousal activation, symbolizing process and more reorganizing experience of reality. The clinical evaluations made by trained judges confirmed the different qualities of emotional processing consistent with the RP linguistic measures.

In the example used to illustrate an arousal dream, we see that the dream was characterized by actions and movements, where parts of the body are named, and where the dream is full of unknown feelings. In the arousal phase there is a struggle to allow emotional activation to occur. In fact, in the example, the first sentence clearly expressed the difficulty to get at, and transform, what had been emotionally activated. The person wrote: Last night's dream was particularly tiring. I still feel the weight of it. The 'weight of it' is a powerful image to indicate difficulty in transforming some activation in the elaboration process. The panic/distress expressed in the dream reaches the reader very strongly given the concreteness of the language used and the persecutory dimension expressed. The dream ended like it began: 'The face that hosts them opens in a malevolent smile and a single word resounds in my head: take! The dream stopped like this and I woke up very tired, even now as I write I feel an incredible tiredness.' It is a heaviness in the beginning and tiredness at the end, with no change. The excitatory character of the dream is transmitted in the crudest way, eliciting a sense of no escape as described by the dreamer.

The dream used to illustrate a symbolizing process, while expressing the same feeling of stagnation and claustrophobia that was captured in the sample arousal dream, had, in addition, a more salient metaphorical dimension. In fact, we can see the use of symbols in the dream, where mould, and the sea, for instance, allude to anguished experiences. In other words, the two clinical examples highlight what Freud (1900) described as thing-presentation and word-presentation.

The third example presented an interesting elaboration of traumatic experience. In the dream of reflection/reorganization the narrative style highlights a continuous cognitive discrepancy between the dream and reality, as if the dreamer constantly tried to explain the incongruity of the surrounding reality and the unreality of the situation. In 
other words, the dream tries to justify reality by attributing a sense to the surreal dimension generated by the virus that imposes a nonsense on the present reality.

Finally, we explored the relationship between linguistic measures and demographic variables. Negative affect had a positive association with age. Although the average age of the participants was not high, the correlation between age and negative affects could indicate the greater fear of getting sick of older people. People in romantic relationships used more negative affect words, than people who were single. This data could be seen as a counterintuitive result, but we know that being in a safe relationship allows the possibility of being able to verbalize negative aspects of the experience. Conversely, people who experience greater loneliness may not be able to allow themselves to express negative feelings directly. Another interpretation that could in the future be explored by comparing dreams with daytime narratives is that perhaps during the night something can be freely expressed that is allowed expression during the day. People in relationships could express their negative affects in dreams while repressing such affects during daytime. Similarly, people who are alone may express their hopes and wishes in their dream to counteraact the negative affect which accompanies their real life. Another interesting result was that participants in psychotherapy reached higher scores of Referential Activity (IWRAD) and lower scores of Sensory-Somatic experience (ISenS). This aspect is interesting as it highlighted a connection between psychotherapy process and the capacity to be in contact with internal emotions, and to express less symptomatic experiences. In Cluster 3, which can be understood as reality meeting emotions and symbols, many dreams were produced by people in psychotherapy. This suggests that psychotherapy facilitates the integration among these three elements.

In conclusion, our preliminary study about narrative quality of dreams and their function on emotional process contributes to a growing line of research in the role that dreams play in processing shared traumatic experience. A future study could broaden the exploratory inquiry by analysing both dreams and the participants' free associations about them. In light of these considerations, our results of Dream Drawer analysis confirmed the function of reorganizing affect triggered by difficult experience in order to face reality.

\section{Limitations}

Many limitations are present in our study. The small sample of dreams does not allow for generalization of the results. The sample, however, allows for a qualitative analysis of the process generated in the narrative exchange of one's dreams in a highly traumatic life context. The study was an exploratory investigation of affective processes in a highly polarized context of reality and therefore cannot be extended to different moments of everyday life. However, we also know that the study of some emotional processes in particular conditions allows for the emergence of phenomena that otherwise would not be evident or would not activate group sharing processes as happened in this specific case. We hope to deepen the qualitative analysis of dreams according to the multiple code theory by verifying the fact that some dreams have a greater connection with emotional activation, while others perform more properly a reorganizing and containing function of the daytime experience.

\section{References}

Barrett, D. (2020). Dreams about COVID-19 versus normative dreams: Trends by gender. Dreaming, 30(3), 216-221. doi: 10.1037/drm0000149

Ben-Meir, M., Bucci, W., \& Bers, S.A. (2009). The language of anorexia nervosa: implications for the 'talking cure'. Journal of the American Psychoanalytic Association, 57(1), 181-187. doi: 10.1177/00030651090570011002

Birksted-Breen, D. (2020). Writing in the time of Covid-19. The International Journal of Psychoanalysis, 101(3), 433-435. doi: 10.1080/00207578.2020.1764749

Bucci, W., Kabasakalian, R., \& the Referential Activity Research Group. (2004). Instructions for scoring Referential Activity $(R A)$ in transcripts of spoken narrative texts. Ulmer Textbank, Ulm, Germany.

Bucci, W. (2008). The role of bodily experience in emotional organization. New perspectives on the multiple code theory. In F. S. Anderson (Eds), Bodies in Treatment. New York, NY: Analytic Press.

Bucci, W. (2021). Overview of the Referential Process: The Operation of Language Within and Between People. Journal of Psycholinguistic Research, 50(1), 3-15. doi: 10.1007/s10936021-09759-2

Christian, C., Hoffman, L., Bucci, W., Crimins, M., \& Worth, M. (2010). Symbolization and emotional engagement in mothers' reports of childcare activities. International Journal of Applied Psychoanalytic Studies, 7(1), 22-39. doi: 10.1002/aps.23

De Gennaro, L., Ferrara, M., Cristiani, R., Curcio, G., Martiradonna, V., \& Bertini, M. (2003). Alexithymia and Dream Recall Upon Spontaneous Morning Awakening. Psychosomatic Medicine, 65(2), 301-306. doi: 10.1097/01.PSY. 0000058373.50240 .71

Di Trani, M., Mariani, R., Renzi, A., Greenman, P.S. \& Solano, L. (2018). Alexithymia according to Bucci's multiple code theory: A preliminary investigation with healthy and hypertensive individuals. Psychology and Psychotherapy: Theory, Research and Practice, 91(2), 232-247. doi: 10.1111/papt. 12158

Freud, S. (1900). The Interpretation of Dreams. London: Hogarth Press.

Freud, S. (1962). Civilization and its discontents. New York, NY: W.W. Norton \& Co.

Gori, A., Topino, E., \& Di Fabio, A. (2020). The protective role of life satisfaction, coping strategies and defense mechanisms on perceived stress due to COVID-19 emergency: A chained mediation model. PLoS One, 15(11), e0242402. doi: 10.1371/journal.pone.0242402

Hair, J., Black, W., Babin, B.J., \& Anderson, R.E. (2009). Multivariate data analysis. New Jersey, USA: Prentice Hall. 
Hartmann, E., \& Basile, R. (2003). Dream imagery becomes more intense after 9/11/01. Dreaming, 13(2), 61-66. doi: 10.1023/ A: 1023398924124

Hoffmann, L., Algus, J., Braun, W., Bucci, W., \& Maskit, B. (2013). Treatment notes: objective measures of language style point to clinical insights. Journal of the American Psychoanalytic Association, 61(3), 535-568. doi: 10.1177/0003065 113489026

Hopper, E. \& Weinberg, H. (2011). The Social Unconscious in Persons, Groups and Societies: Mainly Theory (Vol.1). London (UK): Karnac Books.

Iorio, I., Sommantico, M., \& Parrello, S. (2020). Dreaming in the time of COVID-19: A quali-quantitative Italian study. Dreaming, 30(3), 199-215. doi: 10.1037/drm0000142

Killgore, W. D. S., Cloonan, S. A., Taylor, E.C., \& Dailey, N.S. (2020). Loneliness: A signature mental health concern in the era of COVID-19, Psychiatry Research, 290, 113117. doi: 10.1016/j.psychres.2020.113117.

Kingsley, G. (2010). The clinical validation of measures of the referential process. Dissertation Abstracts International: The Sciences and Engineering, 70, 9-B.

Kleinberg, B., Vegt, I., \& Mozes, M. (2020). Measuring Emotions in the COVID-19 Real World Worry Dataset. ArXiv, $\mathrm{abs} / 2004.04225$.

Jepson, L., \& Bucci, W. (1999). Object relations and referential activity in physically abused adolescents. Adolescence, 34, 780-792. PMID: 10730703

Lahire, B. (2020). The Sociological Interpretation of Dreams. Cambridge (UK): Polity Press.

Lambert, A., Cayouette-Remblière, J., Guéraut, É., Le Roux, G., Bonvalet, C., Girard, V. \& Langlois, L. (2020). Neighbourliness during lockdown in France. Population \& Societies, 578(6), 1-4. doi: 10.3917/popsoc.578.0001

Lane, R.D., Ryan, L., Nadel, L. \& Greenberg, L. (2015). Memory reconsolidation, emotional arousal, and the process of change in psychotherapy: New insights from brain science. The Behavioral and Brain Science, 38(1). doi: 10.1017/ S0140525X14000041.

Lawrence, W.G. (1998). Social dreaming as a tool of consultancy and action research. In W.G. Lawrence (Ed.), Social Dreaming at Work. London: Karnak Book.

LeDoux, J. E. (1996). The Emotional Brain. New York, NY: Simon \& Schuster.

Lumley, M. A., \& Bazydlo, R. A. (2000). The relationship of alexithymia characteristics to dreaming. Journal of Psychosomatic Research, 48(6), 561-567. doi: 10.1016/S0022-3999(00) 00096-9

MacKay, C., \& DeCicco, T. L. (2020). Pandemic dreaming: The effect of COVID-19 on dream imagery, a pilot study. Dreaming, 30(3), 222-234. doi: 10.1037/drm0000148

Margherita, G., Gargiulo, A., \& Martino, M. L. (2015). Dream narration in healthy and at-risk pregnancy. Dreaming, 25(2), 88-102. doi: 10.1037/a0038884

Mariani, R., \& De Coro, A. (2013). Study of a short-term treatment by referential activity linguistic measures. Research in Psychotherapy: Psychopathology, Process and Outcome, 16(1), 42-53. doi 10.4081/ripppo.2013.122.

Mariani, R., Maskit, B., Bucci, W., \& De Coro, A. (2013). Linguistic measures of the referential process in psychodynamic treatment: the English and Italian versions. Psychotherapy Research, 23(4), 430-447. doi: 10.1080/10503307.2013. 794399

Maskit, B. (2021). Overview of Computer Measures of the Ref- erential Process. Journal of Psycholinguist Research, 50, 2949. doi: 10.1007/s10936-021-09761-8

Maskit, B. (2014). The Discourse Attributes Analysis Program (DAAP) Operating Instructions. figshare doi: 10.6084/m9. figshare. 947740

Masiero, M., Mazzocco, K., Harnois, C., Cropley, M., \& Pravettoni, G. (2020). From Individual To Social Trauma: Sources Of Everyday Trauma In Italy, The US And UK During The Covid-19 Pandemic. Journal of Trauma Dissociation, 12, 17. doi: 10.1080/15299732.2020.1787296.

Miermont-Schilton, D., \& Richard, F. (2020). The current sociosanitary coronavirus crisis: remote psychoanalysis by Skype or telephone. The International Journal of Psychoanalysis, 101(3), 572-579. doi: 10.1080/00207578.2020. 1773633

Miller, K.E., Brownlow, J.A., Woodward, S., \& Gehrman, P.R. (2017). Sleep and Dreaming in Posttraumatic Stress Disorder. Current Psychiatry Reports, 19(10), 71. doi: 10.1007/s11920017-0827-1

Mota, N.B., Weissheimer, J., Ribeiro, M., de Paiva, M., AvillaSouza, J., Simabucuru, G., Chaves, M.F., Cecchi, L., Cirne, J., Cecchi, G., Rodrigues, C., Copelli, M., \& Ribeiro, S. (2020). Dreaming during the Covid-19 pandemic: Computational assessment of dream reports reveals mental suffering related to fear of contagion. PLoS One, 15(11), e0242903. doi: 10.1371/journal.pone.0242903.

Museum of London (2020). Museum of Dreams project (Creator Sliwinski, S.). Retrieved from: https://www.museumoflondon.org.uk/news-room/press-releases/museum-london-collect-covid-dreams

Negri, A., Andreoli, G., Mariani, R., De Bei, F., Rocco, D., Greco, A., \& Bucci, W. (2020). First Validation of the Referential Process Post session Scale - Therapist version (RPPS-T). Clinical Neuropsychiatry, 17(6), 319-329. doi: 10.36131/cnfioritieditore20200601

Negri, A., Esposito, G., Mariani, R., Savarese, M., Belotti, L., Squitieri, B., \& Bucci, W. (2018). The Italian weighted reflection and reorganization list (I-WRRL): A new linguistic measure detecting the third phase of the referential process. Paper presented at: XII Congresso Nazionale della Società per la Ricerca in Psicoterapia SPR-Italia, Palermo, Italy.

Neri, C. (2004). Presentazione del metodo e della tecnica del Social Dreaming. Relazione sui workshops tenuti a Lem-al-dar, Mauriburg, Raissa e Clarice Town. In W.G. Lawrence (Ed.), Esperienze nel Social Dreaming. Roma: Borla.

Osserman, J., \& Lê, A. (2020). Waiting for other people: a psychoanalytic interpretation of the time for action. Wellcome Open Research, 5, 133. doi: 10.12688/wellcomeopenres. 15959.1

Pesonen, A. K., Lipsanen, J., Halonen, R., Elovainio, M., Sandman, N., Makela, J. M., Antila, M., Béchard, D., Ollila, H.M., \& Kuula, L. (2020). Pandemic dreams: network analysis of dream content during the COVID-19 lockdown. Frontiers in Psychology, 11, 2569. doi: 10.3389/fpsyg. 2020.573961

Schredl, M., \& Piel, E. (2006). War-Related Dream Themes in Germany from 1956 to 2000. Political Psychology, 27(2), 299-307. doi: 10.1111/j.1467-9221.2006.00008.x

Schredl, M. (2012). Continuity in studying the continuity hypothesis of dreaming is needed. International Journal of Dream Research, 5, 1-8. doi: 10.11588/ijodr.2012.1.9306

Severino, S.K., Bucci, W., \& Creelman, M.L. (1989). Cyclical changes in emotional information processing in sleep and 
dreams. Journal of American Academy of Psychoanalysis, 17(4), 555-577. doi: 10.1521/jaap.1.1989.17.4.555.

Solms, M. (2001). The Interpretation of Dreams and the Neurosciences. Psychoanalysis and History, 3. doi: 10.3366/pah. 2001.3.1.79.

Soraci, P., Ferrari, A., Abbiati, F.A., Del Fante, E., De Pace, R., Urso, A., \& Griffiths, M.D. (2020). Validation and Psychometric Evaluation of the Italian Version of the Fear of COVID-19 Scale. International Journal of Mental Health and Addiction, 4, 1-10. doi: 10.1007/s11469-020-00277-1.

Souza, J. C., Pettengill, E. C., \& Pettengill, C. A. (2020). Psychosocial Aspects of Quarantine, Social Isolation and Social Distance. Psychology, 11(8), 1200-1214. doi: 10.4236/psych. 2020.118080

Taylor, G. J. (1987). Psychosomatic medicine and contemporary psychoanalysis. Madison, CT: International Universities Press.
Townsend, S. S. M., Eliezer, D., \& Major, B. (2013). The embodiment of meaning violations. In K. D. Markman, T. Proulx, \& M. J. Lindberg (Eds.), The psychology of meaning. American Psychological Association. doi: 10.1037/14040-019

Venuleo, C., Gelo, C. G. O., \& Salvatore, S. (2020). Fear, affective semiosis, and management of the pandemic crisis: COVID19 as semiotic vaccine? Clinical Neuropsychiatry, 17(2), 117130. doi: $10.36131 / \mathrm{CN} 20200218$

Whelton, W.J. (2004). Emotional processes in psychotherapy: evidence across therapeutic modalities. Clinical Psychology \& Psychotherapy, 11(1), 58-71. doi: 10.1002/cpp.392

Zhou, Y., Maskit, B., Bucci, W., Fishman, A., \& Murphy, S. (2021). Development of WRRL: A New Computerized Measure of the Reflecting/Reorganizing Function. Journal of Psycholinguistic Research, 50, 51-64. doi: 10.1007/ s10936-021-09762-7 